\title{
Nutritive Value Variation and In Vitro Digestibility of Hempseed Meal
}

\author{
Kristen June Jacobson ${ }^{1,2}$, Lea Ann Kinman ${ }^{1}$, Walter Franklin Owsley ${ }^{1}$, James Pierre Muir ${ }^{2,3}$ \\ and William Brandon Smith 1,*,+iD
}

1 Department of Animal Science, Tarleton State University, Stephenville, TX 76401, USA; sw_jacobson@tarleton.edu (K.J.J.); kinman@tarleton.edu (L.A.K.); owsley@tarleton.edu (W.F.O.)

2 Texas A\&M AgriLife Research, Stephenville, TX 76401, USA; jim.muir@ag.tamu.edu

3 Department of Wildlife and Natural Resources, Tarleton State University, Stephenville, TX 76401, USA

* Correspondence: wbs0001@auburn.edu

† Current address: Department of Animal Science, Auburn University, Auburn, AL 35201, USA.

check for updates

Citation: Jacobson, K.J.; Kinman, L.A.; Owsley, W.F.; Muir, J.P.; Smith, W.B. Nutritive Value Variation and In Vitro Digestibility of Hempseed Meal. Animals 2021, 11, 3481. https:// doi.org/10.3390/ani11123481

Academic Editor:

Mariangela Caroprese

Received: 19 November 2021

Accepted: 6 December 2021

Published: 7 December 2021

Publisher's Note: MDPI stays neutral with regard to jurisdictional claims in published maps and institutional affiliations.

Copyright: (c) 2021 by the authors. Licensee MDPI, Basel, Switzerland. This article is an open access article distributed under the terms and conditions of the Creative Commons Attribution (CC BY) license (https:// creativecommons.org/licenses/by/ $4.0 /)$.
Simple Summary: While there have been international studies on hemp as a livestock feed source, information is limited in the U.S.A. Hempseed meal, the byproduct of oil production, is relatively unexplored. Our research focused on determining variability among hemp seed meal sources and batches within sources, through chemical analysis and in vitro digestibility of samples. Our research found nutritive value variability among batches, but not sources, of hempseed meal. In vitro digestibility only slightly decreased when hempseed meal was included at increasing percentages as a protein replacement in the ration. These data indicate that hempseed meal may be an effective source of crude protein for inclusion in ruminant livestock rations.

Abstract: Hempseed meal (HSM) is left after oil extraction of hemp and may act as a protein source in livestock. The first phase of this research evaluated variation in nutritive value and in vitro dry matter digestibility (IVDMD) of HSM from various sources in North America; the second phase utilized IVDMD to evaluate the efficacy of hempseed meal as an ingredient in ruminant feed. In phase one, the source had no contribution to variance for neutral detergent fiber (NDF), acid detergent fiber $(\mathrm{ADF})$, acid detergent lignin (ADL), or crude protein (CP) $(p \geq 0.20)$. However, batch within source contributed to variation for NDF (50\%), $\operatorname{ADF}(37 \%), \operatorname{ADL}(13 \%)$, and CP (31\%; $p \leq 0.01)$. Irrespective of differences in nutritive value, there was no contribution to variation $(p=0.23)$ of any measured response on in vitro true digestibility (53.0\%). In phase two, two experiments evaluated HSM IVDMD as (1) a concentrate replacement or (2) a protein replacement in rations at varying rates. In the first experiment, IVDMD decreased $(p<0.05)$ with increasing levels of HSM. In the second experiment, IVDMD decreased $(p<0.01)$ as HSM inclusion increased. Although IVDMD decreased as HSM inclusion increased, values still met the digestibility threshold for ruminant rations, indicating that HSM has potential as an alternative protein ingredient.

Keywords: Cannabis sativa; hemp; hempseed meal; nutritive value; variability; ruminants

\section{Introduction}

Recent US 2018 Farm Bill hemp legislation may open the way for an alternative livestock feed protein source. Hemp and marijuana are both derived from the plant Cannabis sativa L., with the sole difference that hemp must contain less than $0.3 \%$ tetrahydrocannabinol (THC), the psychoactive component in the plant [1]. Over time, marijuana and hemp have been selectively bred to contain differing cannabidiol (CBD) and THC levels. While there is genetic differentiation between the two, both have similar variation and are no more genetically distant from one another than from other strains within their subgroup [2].

Hemp oil, derived from C. sativa seed, has gained popularity over recent years for its use in cosmetics, pharmaceuticals, and human food products [3]. When oil is extracted 
from hemp seeds through either chemical or mechanical methods, a high-protein hempseed meal (HSM) remains [4]. Hempseed meal composition is dependent on plant and seed quality prior to oil extraction, which can be affected by weather, location of growth, and variation in plants, among other factors [3]. The crude protein content of HSM ranges between 316 and $356 \mathrm{~g} \mathrm{~kg}^{-1}$ [4-8]. Data on fiber content are limited, with NDF values of 372 to $507.9 \mathrm{~g} \mathrm{~kg}^{-1}$ [4-7].

North American hemp industry growth as a result of the 2018 Farm Bill may prove beneficial to the livestock industry. Alternative feed sources are continually being evaluated to advance production efficiency and profitability. While there have been studies on hemp as a livestock feed source, information is limited, especially on U.S.-grown hemp. As of the time of this publication, HSM has not been approved as a feed ingredient by either the Food and Drug Administration or the Association of American Feed Control Officials. Our objectives were to evaluate variation in nutritive value and in vitro dry matter digestibility (IVDMD) among commercial hempseed meal sources and batches, and to determine the potential of hempseed meal as a feed ingredient for ruminant rations.

\section{Materials and Methods}

\subsection{Sample Collection}

Hemp processing facilities within the United States of America that used cold pressing as the method of oil extraction were contacted to obtain HSM samples. Processors were asked to provide distinct samples from as many batches as possible. All hemp seed was collected from C. sativa plants containing less than 0.3\% THC per the 2018 Farm Bill [1].

\subsection{Variability in Nutritive Value}

Upon receipt, HSM samples were dried in a forced-air oven at $55^{\circ} \mathrm{C}$ until weight loss ceased. Samples were then ground to pass through a $2-\mathrm{mm}$ screen in a Wiley mill (Arthur H. Thomas Co., Philadelphia, PA, USA); a subsample was ground to pass through a 1-mm screen.

The experimental design for determining the source of variation was completely randomized. A total of four processing facilities and 15 hempseed meal batches were represented in the experiment. Four laboratory replicates of each batch $\times$ source combination were assayed.

Carbon and nitrogen concentrations were determined by combustion using the Dumas total combustion method in a Leco Cornerstone CN 828 (Elementar Americas, Mt. Laurel, NJ, USA; Method 990.09) [9]. Nitrogen concentration was used to calculate crude protein (CP) content by multiplying by 6.25 [10]. Neutral detergent fiber (NDF), acid detergent fiber (ADF), and acid detergent lignin (ADL) were measured with the ANKOM ${ }^{200}$ Fiber Analyzer (ANKOM Technology Corporation, Fairport, NY, USA) using modified methods [11] originally described by [12]. Acid detergent lignin was measured by the sulfuric acid method (Method 973.18) [9] An ANKOM Daisy II incubator (ANKOM Technology Corporation, Fairport, NY, USA) was used to determine in vitro true digestibility (IVTD) using a modification [11] of the in sacco disappearance method originally described by [13]. Rumen fluid was collected from a ruminally-fistulated steer at the Texas A\&M AgriLife Research and Extension Center in Stephenville TX. The steer was offered ad libitum access to 'Coastal' bermudagrass (Cynodon dactylon [L.] Pers.) hay with a minimum $120 \mathrm{~g} \mathrm{CP} \mathrm{kg}^{-1} \mathrm{DM}$.

\subsection{In Vitro Dry Matter Digestibility Experiments}

The experimental design for each of the experiments in which the effect of HSM inclusion on IVDMD was evaluated was a generalized complete block design. Block was designated as a single rumen fluid collection, and each experiment included two blocks. Each dietary treatment was replicated three times within each block, with the flask serving as the experimental unit.

The HSM used in mixtures for the in vitro experiments was a composite of the 15 batches collected from four oil processing factories ( $336 \mathrm{~g} \mathrm{CP} \mathrm{kg}^{-1} \mathrm{DM}$ ). Steam flaked 
corn (Zea mays L.), bermudagrass hay, alfalfa (Medicago sativa L.) pellets, and soybean (Glycine max L.) meal were purchased at a local feed store. All ingredients were ground to pass through a 2-mm screen in a Wiley mill (Arthur H. Thomas Co., Philadelphia, PA, USA). In the first experiment, HSM replaced the concentrate (steam-flaked corn) in a 60:40 forage-to-concentrate ratio mixture at $0,250,500,750$, and $1000 \mathrm{~g} \mathrm{~kg}^{-1}$. The forage in this mixture was bermudagrass hay. In the second experiment, isonitrogenous (book value) mixtures were formulated in which HSM replaced soybean meal and alfalfa at 0, 250, 500 , and $750 \mathrm{~g} \mathrm{~kg}^{-1}$. The complete composition of feeds tested in both experiments are presented in Table 1.

Table 1. Composition $\left(\mathrm{g} \mathrm{kg}^{-1}\right)$ of feed mixtures tested in the in vitro experiments of hempseed meal digestibility.

\begin{tabular}{|c|c|c|c|c|c|c|c|c|c|}
\hline \multirow[b]{2}{*}{ Feedstuff } & \multicolumn{5}{|c|}{$\begin{array}{c}\text { Experiment 1: Hempseed Meal Replacement of } \\
\text { Concentrate, } \mathrm{g} \mathrm{kg}^{-1}\end{array}$} & \multicolumn{4}{|c|}{$\begin{array}{c}\text { Experiment 2: Hempseed Meal Replacement of } \\
\text { Dietary Crude Protein, } \mathrm{g} \mathrm{kg}^{-1}\end{array}$} \\
\hline & 0 & 250 & 500 & 750 & 1000 & 0 & 250 & 500 & 750 \\
\hline Steam-flaked corn & 600 & 450 & 300 & 150 & - & 310 & 310 & 310 & 315 \\
\hline Bermudagrass hay & 400 & 400 & 400 & 400 & 400 & - & - & 120 & 250 \\
\hline Alfalfa meal pellets & - & - & - & - & - & 620 & 530 & 280 & - \\
\hline Soybean meal & - & - & - & - & - & 70 & 15 & - & - \\
\hline Hempseed meal & - & 150 & 300 & 450 & 600 & - & 145 & 290 & 435 \\
\hline \multicolumn{10}{|l|}{ Nutritive value } \\
\hline NDF & - & - & - & - & - & 295 & 284 & 326 & 340 \\
\hline $\mathrm{ADF}$ & - & - & - & - & - & 213 & 210 & 220 & 207 \\
\hline ADL & - & - & - & - & - & 50 & 59 & 59 & 53 \\
\hline $\mathrm{CP}$ & - & - & - & - & - & 120 & 140 & 150 & 190 \\
\hline
\end{tabular}

Modified methods of the procedure originally described by [14] were utilized. For each experiment, $0.5 \mathrm{~g}$ samples were weighed into $125 \mathrm{~mL}$ Erlenmeyer flasks with $40 \mathrm{~mL}$ of a 1:5 ratio of buffer solution $B$ and buffer solution A [15]. Ten $\mathrm{mL}$ of $\mathrm{CO}_{2}$-flushed rumen fluid collected from a ruminally-fistulated steer was then added to each flask. Flasks were sealed with a rubber stopper fitted with an airlock, placed in a Fisherbrand Isotemp Shaking Water Bath (Thermo Fisher Scientific, Newington, NH, USA) at $39^{\circ} \mathrm{C}$, and agitated at $30 \mathrm{RPM}$ for $48 \mathrm{~h}$. Then, $2 \mathrm{~mL} \mathrm{HCl}$ and $0.5 \mathrm{~g}$ pepsin were added to each flask, and stoppers were removed. After $48 \mathrm{~h}$, samples were filtered through P8 filter paper and dried for $2 \mathrm{~h}$ at $105^{\circ} \mathrm{C}$.

\subsection{Statistical Analysis}

Data were analyzed using SAS v. 9.4 (SAS Institute, Inc., Cary, NC, USA). Prior to analysis, raw data were tested using the NORMAL option of PROC UNIVARIATE to ensure data normality. Normality was assumed when Shapiro-Wilk's $W$ met or exceeded $0.9[16,17]$.

For the experiment evaluating the source of variation in nutritive value, response variables were analyzed using the linear mixed model procedure (PROC MIXED) in SAS using the COVTEST option for random-effects models. Random effects included source (processor), batch within source, and replicate within batch by source (replicate was understood to represent the laboratory replicate and not a statistical replicate).

For the IVDMD experiments, response variables were analyzed using the generalized linear mixed models procedure (PROC GLIMMIX) in SAS. The fixed effect was treatment, and the random effects were block and treatment by block. Orthogonal polynomial contrasts were tested for linear and quadratic effects of HSM inclusion. Coefficients for contrasts were determined using PROC IML. In experiment 1 , linear coefficients were $-0.63,-0.32,0,0.32$, and 0.63 for $0,250,500,750$, and $1000 \mathrm{~g} \mathrm{HSM} \mathrm{kg}^{-1}$ feed mixture, respectively. Quadratic coefficients were $0.53,-0.27,-0.53,-0.27$, and 0.53 for $0,250,500$, 750 , and $1000 \mathrm{~g} \mathrm{HSM} \mathrm{kg}^{-1}$ feed mixture, respectively. In experiment 2, linear coefficients were $-0.67,-0.22,0.22$, and 0.67 for $0,250,500$, and $750 \mathrm{~g} \mathrm{HSM} \mathrm{CP} \mathrm{kg}^{-1}$ feed mixture 
$\mathrm{CP}$, respectively. Quadratic coefficients were $0.5,-0.5,-0.5$, and 0.5 for $0,250,500$, and $750 \mathrm{~g} \mathrm{HSM} \mathrm{CP} \mathrm{kg}^{-1}$ feed mixture CP, respectively.

For all experiments, denominator degrees of freedom were adjusted using the KenwardRoger approximation method [18]. The $\alpha$-level for mean differences was set at 0.05 . When interactions had $p<\alpha$, the interaction was discussed; otherwise, the main effects were discussed. Means separations were performed based on $F$-protected $t$-tests using TukeyKramer's HSD.

\section{Results}

\subsection{Variability in Nutritive Value}

Mean, median, minimum, and maximum values of nutritive value of HSM are presented in Figure 1. Source had no contribution to variance for NDF, ADF, ADL, or CP (Table 2; $p \geq 0.20$ ). However, batch within source contributed to variation for NDF $(\mu=50.9 \% ; p=0.01)$, ADF $(\mu=36.8 \% ; p=0.01)$, ADL $(\mu=12.9 \% ; p<0.01)$, and CP $(\mu=30.9 \% ; p<0.01)$. Regardless of the differences in nutritive value, there was no contribution to variation $(p \geq 0.23)$ of any measured effect on IVTD $(\mu=53.0 \%)$. Therefore, while variation existed among HSM samples with respect to nutritive value, digestibility was not affected.

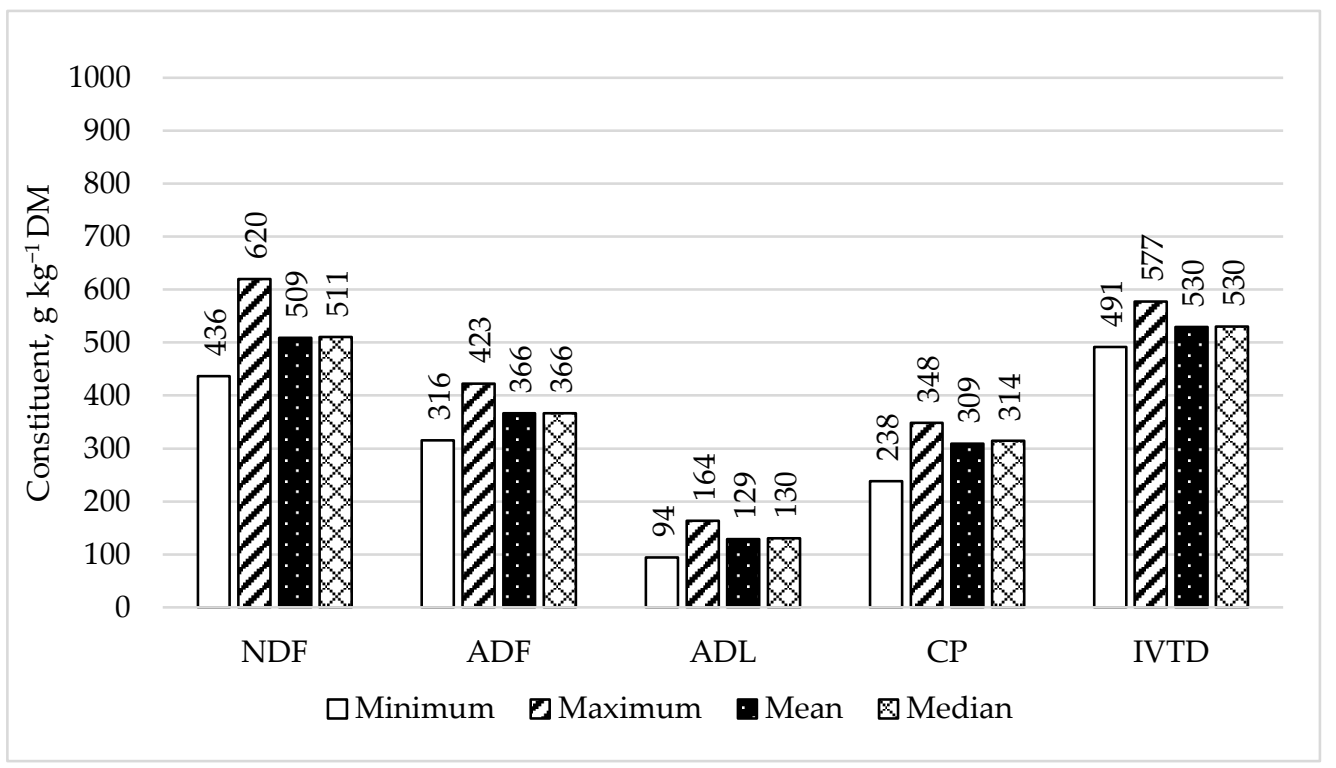

Figure 1. Minimum, maximum, mean, and median observations for neutral detergent fiber (NDF), acid detergent fiber (ADF), acid detergent lignin (ADL), crude protein (CP), and in vitro true digestibility (IVTD) of 15 hempseed meal samples collected from four oil processing facilities.

Table 2. Random effects estimates of neutral detergent fiber (NDF), acid detergent fiber (ADF), acid detergent lignin (ADL), crude protein (CP), and in vitro true digestibility (IVTD) from 15 hempseed meal samples collected from four oil processing facilities.

\begin{tabular}{cccccc}
\hline Effect & Estimate & SE $^{\mathbf{1}}$ & Z-Value & $p$-Value & $\begin{array}{c}\text { Contribution } \\
\text { to Variance }{ }^{2}\end{array}$ \\
\hline $\begin{array}{c}\text { Rep (source by batch) } \\
\text { Batch (source) }\end{array}$ & 0 & NDF & & - & - \\
Source & 0.000969 & 0.000434 & 2.23 & 0.01 & 65.08 \\
Residual & 0.000520 & 0.000134 & - & - & - \\
\hline
\end{tabular}


Table 2. Cont.

\begin{tabular}{cccccc}
\hline Effect & Estimate & SE ${ }^{\mathbf{1}}$ & Z-Value & $p$-Value & $\begin{array}{c}\text { Contribution } \\
\text { to Variance }{ }^{2}\end{array}$ \\
\hline Rep (source by batch) & 0 & ADF & & & - \\
Batch (source) & 0.000381 & 0.000172 & 2.21 & 0.01 & 44.82 \\
Source & 0.000375 & 0.000441 & 0.85 & 0.20 & 44.12 \\
Residual & 0.000094 & 0.000024 & 3.87 & $<0.01$ & 11.06 \\
\hline Rep (source by batch) & 0 & ADL & & & - \\
Batch (source) & 0.000287 & 0.000121 & 2.38 & $<0.01$ & 68.50 \\
Source & 0.000096 & 0.000143 & 0.67 & 0.25 & 22.91 \\
Residual & 0.000036 & 0.000009 & 3.87 & $<0.01$ & 8.59 \\
\hline Rep (source by batch) & 0 & CP & & & - \\
Batch (source) & 0.000964 & 0.000371 & 2.60 & $<0.01$ & 96.50 \\
Source & 0 & - & - & - & - \\
Residual & 0.000035 & 0.000013 & 2.74 & $<0.01$ & 3.50 \\
\hline Rep (source by batch) & 0 & IVTD & & & - \\
Batch (source) & 0.000050 & 0000068 & 0.73 & 0.23 & 9.58 \\
Source & 0 & - & - & - \\
Residual & 0.000472 & 0.000100 & 4.74 & $<0.01$ & 90.42 \\
\hline
\end{tabular}

${ }^{1} \mathrm{SE}=$ standard error. ${ }^{2}$ Contribution to variance is measured as the percent of the total variance accounted for by the measured effect.

\subsection{In Vitro Dry Matter Digestibility}

In the first experiment, IVDMD decreased linearly $(p<0.01)$ with increasing HSM inclusion (Table 3). Feed mixture IVDMD was greatest $(p<0.05)$ from $0 \mathrm{~g} \mathrm{HSM} \mathrm{kg}^{-1}$ feed $\left(406 \mathrm{~g} \mathrm{~kg}^{-1}\right)$ and least from $1000\left(225 \mathrm{~g} \mathrm{~kg}^{-1}\right)$, with 250, 500, and 750 intermediate (Table 3).

Table 3. In vitro dry matter digestibility (IVDMD) of a 60:40 forage-to-concentrate ratio mixture in which hempseed meal replaced the concentrate portion at various levels.

\begin{tabular}{|c|c|c|c|c|c|c|c|}
\hline & \multicolumn{5}{|c|}{ Hempseed Meal Replacement of Concentrate, $\mathrm{g} \mathrm{kg}^{-1}$} & \multicolumn{2}{|c|}{ Contrasts } \\
\hline & 0 & 250 & 500 & 750 & 1000 & Linear & Quadratic \\
\hline $\begin{array}{c}\text { IVDMD, } \\
\mathrm{g} \mathrm{kg}^{-1} \mathrm{DM}\end{array}$ & $406^{\mathrm{a}}$ & $379 \mathrm{ab}$ & $332 \mathrm{ab}$ & $285^{\mathrm{ab}}$ & $225^{b}$ & $<0.01$ & 0.56 \\
\hline
\end{tabular}

In the second experiment, IVDMD, again, decreased linearly $(p<0.01)$ with HSM inclusion. However, this level of inclusion was based on dietary CP rather than absolute ratios of feed ingredients. Feed mixture IVDMD was greatest $(p<0.05)$ at $0\left(771 \mathrm{~g} \mathrm{~kg}^{-1}\right)$, followed by 250 and 500, and least from 750 (643 $\mathrm{g} \mathrm{kg}^{-1}$; Table 4).

Table 4. In vitro dry matter digestibility (IVDMD) of isonitrogenous rations in which hempseed meal replaced the crude protein portion at various levels.

\begin{tabular}{ccccccc}
\hline & \multicolumn{3}{c}{ Hempseed Meal Replacement of Crude Protein, } & \multicolumn{2}{c}{ Contrasts } \\
\cline { 2 - 6 } $\mathbf{g ~ k g ~}^{-1}$ & $\mathbf{2 5 0}$ & $\mathbf{5 0 0}$ & $\mathbf{7 5 0}$ & Linear & Quadratic \\
\hline $\begin{array}{c}\text { IVDMD, } \\
\mathrm{g} \mathrm{kg}^{-1} \mathrm{DM}\end{array}$ & $771^{\mathrm{a}}$ & $716^{\mathrm{b}}$ & $693^{\mathrm{b}}$ & $643^{\mathrm{c}}$ & $<0.01$ & 0.86 \\
$\begin{array}{l}\mathrm{a}-\mathrm{c} \text { Different letters indicate significant differences in values }(p<0.05) \\
\text { difference. }\end{array}$
\end{tabular}




\section{Discussion}

\subsection{Variability in Nutritive Value}

Table 5 shows the chemical analysis of HSM from various studies. Hempseed meal crude protein $(\mathrm{CP})$ is comparable to that of other common protein feed sources. A study performed in Italy that examined 20 hemp genotypes from differing geographical locations all grown under the same conditions, found $\mathrm{CP}$ contents to range from 316 to $356 \mathrm{~g} \mathrm{~kg}^{-1}$ with an average of $337 \mathrm{~g} \mathrm{~kg}^{-1}$ [8]. In a Hemp Feed Coalition summary of certificates of analysis from 39 sources of American-grown and -processed HSM of three varieties from 10 states, the average CP content was $335 \mathrm{~g} \mathrm{~kg}^{-1}$ [19]. Other studies found similar CP values [4-7], and our present study was in agreement with these findings.

Table 5. Nutritive value parameters of hempseed meal samples from published literature.

\begin{tabular}{|c|c|c|c|c|c|c|}
\hline Cultivar & Extraction Method & $\mathrm{CP}^{1}$ & $\mathrm{NDF}^{2}$ & $\mathrm{ADF}^{3}$ & $\mathrm{ADL}^{4}$ & Reference \\
\hline CAN19 & Chemical & 345 & - & - & - & [8] \\
\hline CAN20 & Chemical & 356 & - & - & - & [8] \\
\hline CAN24 & Chemical & 331 & - & - & - & [8] \\
\hline CAN 26 & Chemical & 345 & - & - & - & [8] \\
\hline CAN39 & Chemical & 320 & - & - & - & [8] \\
\hline CAN40 & Chemical & 354 & - & - & - & [8] \\
\hline CAN48 & Chemical & 339 & - & - & - & [8] \\
\hline CAN51 & Chemical & 336 & - & - & - & [8] \\
\hline CAN58 & Chemical & 346 & - & - & - & [8] \\
\hline Finola & Chemical & 317 & - & - & - & [8] \\
\hline Carmagnola & Chemical & 334 & - & - & - & [8] \\
\hline CS & Chemical & 316 & - & - & - & [8] \\
\hline Fibranova & Chemical & 325 & - & - & - & [8] \\
\hline Fedora & Chemical & 339 & - & - & - & [8] \\
\hline Futura 75 & Chemical & 337 & - & - & - & [8] \\
\hline Felina 32 & Chemical & 343 & - & - & - & [8] \\
\hline Ferimon & Chemical & 344 & - & - & - & [8] \\
\hline Codimono & Chemical & 336 & - & - & - & [8] \\
\hline Carmaleonte & Chemical & 345 & - & - & - & [8] \\
\hline Kc Dora & Chemical & 332 & - & - & - & [8] \\
\hline Various & Cold-pressed & 335 & 436 & 346 & - & [19] \\
\hline Finola & Cold-pressed & 385 & 449 & - & - & [20] \\
\hline Finola & Cold-pressed & 369 & 434 & - & - & [20] \\
\hline- & - & 344 & 393 & 103 & - & {$[7]$} \\
\hline Finola & Cold-pressed & 336 & 382 & 336 & - & [4] \\
\hline- & - & 320.8 & 507.9 & 390.4 & 131.9 & [5] \\
\hline Carmagnola & Chemical & 337 & - & - & - & [21] \\
\hline CS & Chemical & 348 & - & - & - & [21] \\
\hline Fibranova & Chemical & 351 & - & - & - & [21] \\
\hline Futura 75 & Chemical & 342 & - & - & - & [21] \\
\hline Felina 32 & Chemical & 351 & - & - & - & [21] \\
\hline Ferimon & Chemical & 331 & - & - & - & [21] \\
\hline Unika-b & Cold-pressed & 249 & 372 & - & - & [6] \\
\hline
\end{tabular}

${ }^{1} \mathrm{CP}=$ crude protein, $\mathrm{g} \mathrm{kg}^{-1} \mathrm{DM} ;{ }^{2} \mathrm{NDF}=$ neutral detergent fiber, $\mathrm{g} \mathrm{kg}^{-1} \mathrm{DM} ;{ }^{3} \mathrm{ADF}=$ acid detergent fiber, $\mathrm{g} \mathrm{kg}^{-1} \mathrm{DM} ;{ }^{4} \mathrm{ADL}=$ acid detergent lignin, $\mathrm{g} \mathrm{kg}^{-1} \mathrm{DM}$.

Neutral detergent fiber (NDF) values from previous studies vary greatly as seen in Table 4 [4-7]. Acid detergent fiber (ADF) values also vary [4,5,7]. Acid detergent lignin (ADL) was only determined in one study [5].

\section{Sources of Nutritive Value Variation}

Temperature affects seed formation in hemp with ideal temperatures $>27^{\circ} \mathrm{C}$ [21]. Protein synthesis may increase when seed filling occurs during periods of high temperatures because of more efficient $\mathrm{N}$ transfer to the seeds [22]. This was supported by the findings 
of [23] in which seeds grown during a year with higher recorded temperatures had greater $\mathrm{CP}$ content than seeds grown the year prior with lower recorded temperatures. Therefore, the temperature may also have had an effect on variability in nutrient composition between HSM batches; however, this is not consistent with the lack of variability among sources in our study regardless of the differing geographical locations.

Grieshop et al. [24] found that growing and processing conditions, as well as varietal differences, all contributed to the nutrient composition of SBM. Processing conditions, including temperature and time, can affect the nutrient composition of SBM.

\subsection{In Vitro Dry Matter Digestibility}

Our observations of IVDMD in the protein replacement mixture were comparable to those of an in vivo feed trial done on sheep where HSM replaced canola meal at 0, 250, 500,750 , and $1000 \mathrm{~g} \mathrm{~kg}^{-1}$, resulting in DM digestibility coefficients of $0.66,0.63,0.64,0.61$, and 0.64 , respectively [5]. These data support our findings and encourage the applicability of HSM as a protein replacement in ruminant rations. Decreases in IVDMD when HSM replaced SBM/alfalfa were less than those observed when HSM replaced steam-flaked corn, but any conclusions on diet suitability should be made with caution without data from feeding experiments to determine effects on DMI and whether there are any anti-nutritional factors present.

Changes in observed IVDMD could be due to a number of interactions of the nutrients in the tested mixtures. While fiber concentrations were not evaluated in experiment 1 , Table 1 shows that total fiber (NDF) ranged by only $50 \mathrm{~g} \mathrm{~kg}^{-1}$, indicating that it is likely not the reason for observed differences. While digestibility values were unsuitable when HSM replaced the concentrate portion of the mixture in experiment 1 , all digestibility values for mixtures with HSM as a protein replacement in experiment 2 had digestibility percentages acceptable for ruminant rations. Although there was a decrease in digestibility as HSM inclusion increased as a protein source in the mixture, the difference was slight, and dry matter digestibility remained sufficient to meet ruminant needs at all levels of inclusion. Further studies with a 100\% HSM inclusion rate and replacement of protein sources more similar in chemical composition are warranted.

\section{Conclusions}

Our research found nutritive value variability among batches of HSM, which can be attributed to a variety of causes including genetics, environmental factors, and processing techniques. However, IVTD was not affected by this variability, and we found no variability among sources of HSM. Hempseed meal IVDMD only slightly decreased when HSM was included at increasing percentages as a protein replacement in the feed mixture, indicating it may be a potential source of supplemental protein in ruminant diets. Data from current publications in combination with the results of this research indicate there is promise for the inclusion of HSM in ruminant rations.

Author Contributions: Conceptualization, K.J.J. and W.B.S.; methodology, K.J.J., J.P.M. and W.B.S.; formal analysis, W.B.S.; investigation, K.J.J.; resources, J.P.M. and W.B.S.; data curation, K.J.J. and W.B.S.; writing—original draft preparation, K.J.J.; writing—review and editing, L.A.K., W.F.O., J.P.M. and W.B.S.; supervision, J.P.M. and W.B.S.; project administration, W.B.S.; funding acquisition, K.J.J. All authors have read and agreed to the published version of the manuscript.

Funding: This research was funded by the Southern Sustainable Agriculture Research and Education Program, administered by the United States Department of Agriculture's National Institute for Food and Agriculture (project GS20-229).

Institutional Review Board Statement: The steer donating the rumen fluid was managed according to the Standard Operating Procedures approved by the Texas A\&M AgriLife Research Agriculture Animal Care and Use Committee SOP \#2018-023A.

Informed Consent Statement: Not applicable. 
Data Availability Statement: The data presented in this study are available on request from the corresponding author. The data are not publicly available due to privacy concerns related to donated samples from commercial entities.

Acknowledgments: This work was made possible by hempseed meal donors San Luis Valley Hemp, IND Hemp, Colorado Hemp Works, and Kentucky Hemp Works. Graduate study was supported by a graduate assistantship from Tarleton State University and a research assistantship from Texas A\&M AgriLife Research Stephenville.

Conflicts of Interest: The funders had no role in the design of the study; in the collection, analyses, or interpretation of data; in the writing of the manuscript, or in the decision to publish the results.

\section{References}

1. United States Congress. 2018 United States Farm Bill. H.R. 2, 115th Congress, Washington, DC, USA. 2018. Available online: https:/ / www.ams.usda.gov/sites / default/ files/media/2018FarmBill.pdf (accessed on 23 August 2021).

2. Sawyer, J.; Stout, J.M.; Gardner, K.M.; Hudson, D.; Vidmar, J.; Butler, L.; Page, J.E.; Myles, S. The genetic structure of marijuana and hemp. PLoS ONE 2015, 10, e0133292. [CrossRef]

3. Pojić, M.; Mišan, A.; Sakač, M.; Hadnađev, T.D.; Šarić, B.; Milovanović, I.; Hadnađev, M. Characterization of byproducts originating from hemp oil processing. J. Agric. Food Chem. 2014, 62, 12436-12442. [CrossRef] [PubMed]

4. Karlsson, L.; Ruiz-Morena, M.; Stern, M.D.; Martinsson, K. Effects of temperature during moist heat treatment on ruminal degradability and intestinal digestibility of protein and amino acids in hempseed cake. Asian-Australas. J. Anim. Sci. 2012, 25, 1559. [CrossRef] [PubMed]

5. Mustafa, A.F.; McKinnon, J.J.; Christensen, D.A. The nutritive value of hemp meal for ruminants. Can. J. Anim. Sci. 1998, 79, 91-95. [CrossRef]

6. Silversides, F.G.; LefranÇois, M.R. The effect of feeding hemp seed meal to laying hens. Br. Poult. Sci. 2005, 46, 231-235. [CrossRef] [PubMed]

7. Karlsson, L.; Finell, M.; Martinsson, K. Effects of increasing amounts of hempseed cake in the diet of dairy cows on the production and composition of milk. Animal 2010, 4, 1854-1860. [CrossRef] [PubMed]

8. Galasso, I.; Russo, R.; Mapelli, S.; Ponzoni, E.; Brambilla, I.M.; Battelli, G.; Reggiani, R. Variability in seed traits in a collection of Cannabis sativa L. genotypes. Front. Plant Sci. 2016, 7, 688. [CrossRef] [PubMed]

9. AOAC. Official Methods of Analysis, 16th ed.; Association of Official Analytical Chemists: Washington, DC, USA, 2000.

10. AOAC. Official Methods of Analysis, 14th ed.; Association of Official Analytical Chemists: Washington, DC, USA, 1984.

11. Vogel, K.P.; Pedersen, J.F.; Masterson, S.D.; Toy, J.J. Evaluation of a filter bag system for NDF, ADF, and IVDMD forage analysis. Crop Sci. 1999, 39, 276-279. [CrossRef]

12. Van Soest, P.J.; Robertson, J.B. Systems of analysis for evaluating fibrous feeds. In Standardization of Analytical Methodology of Feeds, Proceedings of the International Workshop, Ottawa, ON, Canada, 12-14 March 1980; Pigden, W.J., Ed.; Unipub: New York, NY, USA, 1980; pp. 49-60.

13. Lowrey, R.S. The nylon bag technique for the estimation of forage quality. In Proceedings of the National Conference on Forage Quality, Evaluation, and Utilization, Lincoln, NE, USA, 14 September 1969; University of Georgia: Athens, GA, USA, 1969; pp. 1-12.

14. Tilley, J.M.A.; Terry, R.A. A two-stage technique for the in vitro digestion of forage crops. Grass Forage Sci. 1963, 18, $104-111$. [CrossRef]

15. ANKOM Technology. Method 3: In Vitro True Digestibility Using the DaisyII Incubator. 2017. Available online: https: //www.ankom.com/sites/default/files/document-files/D200_D2001_Manual.pdf (accessed on 23 August 2021).

16. Shapiro, S.S.; Wilk, M.B. An analysis of variance test for normality (complete samples). Biometrika 1965, 52, 591-611. [CrossRef]

17. Royston, P. Approximating the Shapiro-Wilk W-Test for non-normality. Stat. Comput. 1992, 2, 117-119. [CrossRef]

18. Kenward, M.G.; Roger, J.H. Small sample inference for fixed effects from restricted maximum likelihood. Biometrics 1997, 53, 983-997. [CrossRef] [PubMed]

19. Hemp Feed Coalition; Loveland, CO, USA. Personal communication, 2021.

20. Hessel, A.; Eriksson, M.; Nadeau, E.; Turner, T.; Johansson, B. Cold-pressed hempseed cake as a protein feed for growing cattle. Acta Agric. Scand. Sect. A 2008, 58, 136-145. [CrossRef]

21. Suriyong, S.; Vearasilp, S.; Krittigamas, N.; Rinmanee, S.; Punyalue, A. Effect of seed maturity on seed physiological quality, oil content and fatty acid composition of hemp seed. Chian Mai Univ. J. Nat. Sci. 2012, 11, 351-358.

22. Sainio, P.P.; Jauhiainen, L.; Hakala, K.; Ojanen, H. Climate changes and prolongation of growing season: Changes in regional potential for field crop production in Finland. Agric. Food Sci. 2009, 18, 171-190. [CrossRef]

23. Russo, R.; Reggiani, R. Evaluation of protein concentration, amino acid profile, and antinutritional compounds in hempseed meal from dioecious and monoecious varieties. Am. J. Plant Sci. 2015, 6, 14-22. [CrossRef]

24. Grieshop, C.M.; Kadzere, C.T.; Clapper, G.M.; Flickinger, E.A.; Bauer, L.L.; Frazier, R.L.; Fahey, G.C. Chemical and nutritional characteristics of United States soybeans and soybean meals. J. Agric. Food Chem. 2003, 51, 7684-7691. [CrossRef] [PubMed] 